\title{
O SENADO NO BRASIL RECENTE política e ajuste fiscal
}

\author{
Maria Rita Loureiro \\ Professora da Fundação Getúlio Vargas de São Paulo e da Faculdade de Economia da USP. \\ Autora, entre outros, do livro Os economistas no governo: gestão econômica e democracia
}

\begin{abstract}
Resumo: Examina-se aqui a lógica da ação do Senado no controle do endividamento público, procurando responder à seguinte pergunta: Será que os ditames da política se impõem sobre as necessidades de controle do déficit e da dívida pública? O marco de referência é a Constituição de 1988 e, mais particularmente, o período de implementação do Plano Real, quando o ajuste fiscal torna-se um dos pontos centrais da agenda governamental.

Palavras-chave: endividamento público; restrições legais; ação política.
\end{abstract}

$\mathrm{O}$ momento atual torna a análise do tema ao mesmo tempo difícil e instigante. Difícil, em primeiro lugar, em função da crise institucional vivida pelo Senado, envolvendo casos de corrupção e de comportamento incompatíveis com o decoro parlamentar; em segundo, porque o ajuste fiscal ficou bastante vulnerável com a crise energética. Esta revelou, na gravidade de suas prováveis conseqüências, a forma extremada e míope da prioridade dada ao ajuste nos últimos anos no País. Não é preciso apontar os enormes danos políticos à imagem do governo, produzidos pelo racionamento e eventual corte de energia: a propósito, vários especialistas dizem que os efeitos do não-investimento no setor energético, a forma como foi conduzido o processo de privatização na área e a falta de planejamento estratégico acabarão, provavelmente, solapando a própria agenda governamental. Até surgirem esses problemas, a agenda parecia cumprida, ao menos nos seus pontos centrais de estabilização monetária, de equilíbrio das contas públicas e de retomada do desenvolvimento.

Por outro lado, a própria crise do Senado estimula estudos sobre essa casa legislativa, que praticamente inexistem na Ciência Política brasileira. Essa lacuna contrasta muito com o número, relativamente grande, de trabalhos produzidos desde a redemocratização, sobre o Congresso, a Câmara dos Deputados e as relações entre Executivo e Legislativo. Dentre eles, destacam-se os de Figueiredo e Limongi (1995 e 1999); Mainwaring (1993 e 1997); Amorim (1994 e 2000); Abranches, (1988); Pessanha, (1997) e Nicolau, (2000).

O presente artigo pretende ajudar a preencher a lacuna, olhando o Senado sob um prisma muito específico: o de sua atuação no processo de controle do endividamento público. O marco de referência é a Constituição de 1988 e, mais particularmente, o período da implementação do Plano Real, quando a questão fiscal torna-se central na agenda do governo.

Cabe esclarecer que a escolha do tema não significa aceitar que se deva realizar o ajuste fiscal a qualquer preço. Ao contrário, mesmo considerando as conseqüências perversas do déficit, ${ }^{1}$ é preciso lembrar, por outro lado, que os governos contemporâneos têm déficits e, por isso se endividam, porque precisam continuar governando. Em outras palavras, os governos tomam empréstimos porque precisam oferecer infra-estrutura e serviços públicos crescentemente reclamados pela população e que, em termos de justiça social, não podem mais ser adiados. Se não responderem a essas demandas, terão sua legitimidade questionada.

Além disso, os efeitos do déficit sobre a economia são objeto de muita controvérsia entre especialistas; e a posição dos políticos ante o problema também varia muito em função da ideologia partidária e da cultura política predominante em cada país. Os responsáveis pelo desenho das instituições econômicas na comunidade européia, por exemplo, não tentaram equilibrar a qualquer custo seus 
orçamentos, mesmo sabendo que o déficit crescente é um problema a considerar (Benavie, 1998). Diferentemente dos políticos conservadores americanos, que reiteradamente pretendem zerar o déficit público, os europeus consideram o investimento (necessário ao desenvolvimento e à expansão do nível de emprego) razão amplamente legítima para o governo se endividar. Aliás, segundo cálculos para os Estados Unidos, cada ponto percentual de desemprego agrega um adicional de cerca de 50 bilhões ao seu déficit público (Ross, 1999). Do ponto de vista normativo, portanto, o que se espera dos governos hoje é a capacidade de manter déficits moderados, evitando tanto os custos elevados do serviço da dívida, quanto os controles extremados do orçamento, que geram recessão e desemprego e, com eles, mais déficit (Evans, 1997:12).

Do ponto de vista teórico, o exame do papel do Senado no estabelecimento de normas de controle do endividamento público remete à discussão dos efeitos das instituições sobre os resultados da ação governamental e sobre a estratégia dos atores políticos; e remete ainda às condições políticas que permitem, ou não, o efetivo cumprimento das regras institucionais, no contexto de conflitos federativos e de constrangimentos macroeconômicos.

Sabe-se bem que o ajuste fiscal é política de difícil implementação em qualquer país democrático, na medida em que implica custos elevados e imediatos e seus benefícios são de longo prazo e mesmo incertos (Schick, 1993; Weaver e Rockman, 1993). Em sistemas federativos, as relações inerentemente complexas e tensas entre poderes autônomos e, ao mesmo tempo, interdependentes, tornam ainda mais dificeis o aumento de impostos, os cortes orçamentários e as medidas restritivas ao endividamento público.

No Brasil, o federalismo tem se pautado por relações competitivas bastante perversas entre os governos, não favorecendo a consolidação de instituições com capacidade de coordenar as relações intergovernamentais e gerar maior cooperação entre eles (Abrucio e Costa, 1998). Além disso, até muito recentemente, predominavam, na área fiscal, práticas predatórias por parte dos estados e municípios que se endividavam sem condições de pagamento, sabendo que a União iria, no final das contas, socorrê-los, transferindo para toda a sociedade o ônus dessas ações (Werneck, 1998).

É dentro desse quadro que a análise do Senado, como câmara de representação federativa, ganha relevância. Assim, procurar-se-á responder aqui às seguintes questões: qual a lógica que orienta sua ação no controle do endividamento público? Será que os ditames da política, das demandas eleitorais e da defesa dos interesses estaduais se impõem sobre as necessidades de controle do déficit e da dívida pública? ${ }^{2}$

O enfoque específico sobre o Senado no controle do endividamento público justifica-se na medida em que, por regra constitucional, ele tem poder privativo para legislar sobre a matéria. O artigo 52 da Constituição de 1988 lhe dá a prerrogativa exclusiva de autorizar operações de natureza financeira para a União, os Estados, os Municípios e as empresas estatais; de estabelecer as condições de financiamento interno e externo e de fixar os limites de endividamento de todos esses entes federativos. Ou seja, não só a União, mas todos os governos subnacionais precisam, para emitir títulos públicos e contratar outras dívidas, do consentimento do respectivo poder legislativo e também de autorização do Senado Federal. ${ }^{3}$ Assim, diferentemente de outros países federativos, os Estados Unidos por exemplo - onde as restrições legais são produzidas de forma descentralizada pelas constituições estaduais e o mercado acaba exercendo o papel mais efetivo (Briffault, 1996; Peterson, 1995; Cligermayer e Dan Wood, 1995) -, no Brasil o controle do endividamento público em qualquer nível de governo é realizado de forma centralizada pelo Senado Federal. ${ }^{4}$

Por essa razão, a mais importante atividade legislativa exclusiva do Senado refere-se ao endividamento público. Cerca de 80\% de suas resoluções, no período de 1989 a 1999 , envolviam autorização para endividamento ou para renegociação de dívidas dos diferentes entes da federação.

$\mathrm{O}$ processo de autorização funciona da seguinte forma: os governos interessados em emitir títulos ou estabelecer contratos de créditos encaminham seus pleitos ao Banco Central que analisa cada caso e em seguida envia ao Senado parecer conclusivo, recomendando ou não a autorização. Uma vez no Senado, o parecer é recebido e discutido pela Comissão de Assuntos Econômicos (CAE), composta por 27 senadores, que aprova ou rejeita o pedido, enviando-o para a decisão final do plenário. Como todos os pareceres emitidos pela Comissão são sempre aprovados no plenário, a CAE acaba sendo o locus decisório central do processo de controle do endividamento público no Brasil.

\section{CRISE FISCAL E NOVAS REGRAS PARA O ENDIVIDAMENTO PÚBLICO}

As causas da crise fiscal dos anos 80 no Brasil remontam a fatores econômicos estruturais, ligados ao esgota- 
mento do modelo de financiamento externo, e ainda ao padrão de relações federativas existentes no País (Sallum Jr. e Kugelmas, 1993; Affonso, 1995; Abrucio e Costa, 1998). É bem conhecido, contudo, que o agravamento das contas públicas, especialmente nos governos subnacionais, decorreu em grande parte da elevação da taxa de juros, imposta pela implementação do Plano Real. Entre 1990 e 1995, por exemplo, os estados viram sua dívida crescer $150 \%$ e acumularam até o final de 1997 um débito de 97 bilhões de dólares. Antes das negociações com a União, que desembocaram na federalização de suas dívidas, 22 estados deviam mais do que um ano de arrecadação. ${ }^{5}$ Em conjunto, a dívida pública no Brasil (incluindo União, estados, municípios e empresas estatais) passou de 35\% do PIB, no início de 1998, para mais de 50\% em abril deste ano. Também os juros pagos pelo setor público passaram de $4 \%$ do PIB, no mesmo período, para mais de $10 \%$ no primeiro trimestre do ano em curso. ${ }^{6}$ Dessa forma, o ajuste fiscal tornou-se mais premente ainda com a estabilização da moeda.

Por outro lado, o equilíbrio das contas públicas impõese sobretudo pela necessidade de integração do País aos mercados financeiros internacionais. Na era da economia globalizada, é preciso oferecer, a despeito dos enormes custos sociais e do comprometimento do próprio desenvolvimento econômico, credibilidade e baixo risco para atrair capitais externos. Como se sabe, o peso da dívida pública em relação ao PIB é o índice que os investidores estrangeiros mais levam em conta para avaliar a "confiabilidade" no país.

Segue-se, assim, que o ajuste fiscal e a geração de superávits primários tornam-se o objetivo central da agenda do governo. ${ }^{7}$ A propósito, com a crise energética, que exige mais investimentos no setor (a ser suprido sobretudo por capitais externos, dada a escassez de poupança interna), e com as incertezas políticas, advindas da proximidade das eleições, os investidores e especuladores estrangeiros têm intensificado, ainda mais, as pressões para a geração de maiores superávits primários e, portanto, menores riscos para seus capitais. ${ }^{8}$

É exatamente por isso que importa analisar a participação do Senado nesse processo, ou seja, como ele desempenha seu papel constitucional de órgão de controle do endividamento público no País, em vista dos constrangimentos econômicos e fiscais. Será que essa casa legislativa apóia o Executivo na realização de sua agenda ou, ao contrário, é um obstáculo, como costumam afirmar vários analistas?
Antes, porém, de examinar o papel do Senado, é necessário retomar, ainda que brevemente, alguns traços que têm marcado as relações federativas no Brasil. De um lado, a Constituição de 1988 deu aos governadores e prefeitos autonomia para fixar alíquotas de impostos, definir estruturas administrativas, fixar salário, aplicar livremente os recursos próprios e as transferências que recebem da União. De outro lado, os estados e municípios caracterizaram-se, até muito recentemente, por comportamento fiscal irresponsável, endividando-se sem condições de pagamento. Sabiam que, no final, transfeririam suas dívidas para a União, através de negociações para "rolar" os débitos (Werneck, 1998).

Nessa moldura político-institucional, que emergiu com a democratização do País e deu grande força política aos governos estaduais, os problemas de financiamento desses governos puderam ser contornados, por mais de uma década, através de dois mecanismos: receitas extraordinárias geradas pelo chamado "imposto inflacionário" (oriundo tanto de reajustes da folha de pessoal em níveis inferiores à taxa de inflação, quanto do prolongamento dos prazos de pagamento de credores); o uso dos bancos estaduais como fonte (não legal) de "quase-emissão" de moeda. Ou seja, através de práticas reiteradas de empréstimos não saldados junto a essas agências financeiras, cujos dirigentes eram nomeados pelos próprios governadores, os governos estaduais conseguiam criar uma fonte alternativa de recursos.

Em 1994, todavia, abre-se nova etapa nas relações intergovernamentais no Brasil (Abrucio e Costa, 1998). Com a estabilização monetária, o fortalecimento do governo federal e da autoridade do Banco Central (Sola; Garman e Marques, 1997), os governos estaduais perderam aquelas duas fontes alternativas de receitas: não só o "imposto inflacionário" desapareceu, mas igualmente os bancos estaduais foram, em maioria, liquidados ou privatizados. Cabe observar que o uso irregular dos bancos estaduais por parte dos governadores contou durante muito tempo com a complacência do Banco Central. Afinal, como já se indicou, o governo federal precisava, para aprovação de sua agenda política no Congresso, do apoio dos governadores que controlavam a bancada parlamentar de seu estado. ${ }^{9}$

Nesse quadro de tensões federativas e de constrangimentos fiscais, observa-se, ao longo dos anos 90, a tendência de o Congresso brasileiro (e o Senado Federal, em particular) legislar em favor da redução das possibilidades de endividamento público. Assim, já em 1993, foi 
promulgada a Emenda Constitucional $\mathrm{n}^{\circ} 3$ que, por seis anos, só permitiria a emissão de títulos públicos por parte de estados e municípios para o refinanciamento de dívidas anteriores; e estabelecia, como única exceção, o financiamento para pagar precatórios judiciais, isto é, dívidas de particulares contra o poder público decididas em juízo. Como emitir títulos públicos para pagar precatórios significava, na prática, criar uma dívida nova, essa foi a única brecha deixada pela legislação para o financiamento dos estados e municípios. Ela foi usada, ao máximo, pelos governos subnacionais como fonte "adicional" de financiamento público. E permitiu, inclusive, muita irregularidade, objeto de farta cobertura da imprensa, o que levou à instalação, em novembro de 1996, de Comissão Parlamentar de Inquérito (CPI).

Se é verdade que os escândalos acerca da emissão irregular de títulos precatórios mostraram a profunda crise financeira em que se encontravam muitos governos subnacionais, estes puderam agir assim porque sabiam que a elevada inflação dificultava sua percepção e fiscalização. Sabiam também, sobretudo, que contavam com a conivência e "flexibilidade" das autoridades encarregadas do controle do endividamento. O próprio relatório da CPI indicou que os Tribunais de Contas dos Estados, o Banco Central e o Senado não estavam exigindo, como condição prévia para autorizar emissão de um novo título, a comprovação do valor das parcelas efetivamente pagas de títulos precatórios, nem tampouco controlavam o índice de correção monetária aplicado aos mesmos. ${ }^{10}$

Se, até o momento, a CPI não resultou na punição dos envolvidos na emissão irregular de títulos precatórios, teve, contudo, um efeito importante: gerou a produção de regras cada vez mais restritivas para o controle do endividamento público no País. Assim, em setembro de 1997, foi sancionada a Lei n ${ }^{\circ}$ 9.496/97 que estabeleceu critérios rígidos para que a União refinanciasse a dívida pública mobiliária dos estados e do Distrito Federal. Em julho de 1998, o Senado baixou a Resolução 78/98, ainda mais rigorosa, que se tornou um marco de referência na consolidação das condições institucionais para o controle do endividamento público no País. Dentre as modificações mais importantes trazidas por essa resolução, cabe destacar:

- o Banco Central não mais encaminhará ao Senado Federal pedido de autorização para a contratação de qualquer operação de crédito (aí incluindo a emissão de títulos da dívida pública) de governo que possua resultado primário negativo;
- os estados que desejarem contratação de operações de crédito, dependentes da aprovação do Senado, não poderão conceder qualquer tipo de isenção fiscal sobre o ICMS, imposto que é sabidamente a maior fonte de arrecadação estadual;

- governadores e prefeitos ficam impedidos de se endividar por meio de operações ARO (Antecipação de Receita Orçamentária) no último ano de mandato;

- prorroga até o ano de 2010 a proibição de emissão de títulos públicos, salvo para o refinanciamento do principal (devidamente atualizado) e proíbe os governos subnacionais que tiverem sua dívida mobiliária refinanciada pela União de emitir, sob qualquer pretexto, novos títulos públicos;

- dentre outras medidas visando a maior transparência nas operações de crédito, estabelece que os governos têm de fazer leilões eletrônicos na contratação de $\mathrm{ARO}$ e que o Banco Central deve dar ampla divulgação dos leilões para colocação dos títulos estaduais no mercado.

Na medida em que o Senado, através da resolução de 1998, já vinha chamando os governadores e prefeitos à responsabilidade fiscal e tentava pôr fim à guerra fiscal, é interessante confrontá-la com a Lei de Responsabilidade Fiscal (LRF), sancionada em maio de 2000. Esta lei estabelece um conjunto mais amplo de regras que não só disciplinam condições e limites de endividamento, como também induzem novos comportamentos nessa área, como o planejamento orçamentário, a transparência das contas públicas e a responsabilidade fiscal. Ela faz isso ao vincular gastos às receitas, ao estabelecer tetos de despesas com pessoal (discriminadas por esfera de poder) e ao proibir o socorro da União aos governos subnacionais. ${ }^{11}$ São regras que consolidam princípios de gestão fiscal que ganharam consenso nos meios governamentais e na mídia, ao longo da última década. As resoluções do Senado, em particular a 78/98, constituíram um ponto de inflexão importante nesse processo. Além de submeter-se aos limites ao endividamento estabelecidos pelo Senado, algumas cláusulas da LRF já estavam contidas na resolução de 1998, como a que proíbe operações ARO no último ano de mandato do chefe do poder executivo e as medidas para maior transparência das contas públicas, aí incluídas as operações de crédito.

Assim, observa-se que o Senado produziu ao longo dos últimos anos um conjunto de normas cada vez mais restritivas para o endividamento dos governos. ${ }^{12}$ A proibição de emissão de títulos públicos por mais de dez anos serve 
O Senado no Brasil Recente: política e ajuste fiscal

de exemplo de seu caráter drástico. Segundo alguns estudiosos, a expansão do mercado primário de títulos estaduais e municipais, como existe nos Estados Unidos, poderia ser uma fonte alternativa importante para financiamento do setor público no país, pois não elevaria a já muito onerosa carga tributária (Ferreira, 1998; Toneto Jr. e Gremaud, 2000).

\section{A LÓGICA DA AÇÃO DO SENADO: POLÍTICA E AJUSTE FISCAL}

Todavia, apesar das restrições crescentes, as novas regras não geraram os efeitos desejados, ao menos à primeira vista. Argüindo estar diante de situações excepcionais, os senadores continuaram aprovando quase todos os pedidos de autorização de endividamento que lhes foram apresentados. Dados levantados no Senado, sistematizados na Tabela 1, mostram que as autorizações para endividamento oscilaram nos últimos anos, em decorrência de vários fatores, não necessariamente derivados das restrições legais. Ou seja, as resoluções mais restritivas não tiveram influência significativa nesse movimento. Por exemplo, mesmo no contexto da já mencionada Lei no 9.496 de 1997, o número total de autorizações naquele ano cresceu quase $20 \%$. No âmbito estadual, a proporção foi ainda maior (mais de 40\%), passando de 52 para 75 autorizações concedidas. Em 1998, o número total de autorizações para os estados e municípios declinou, mas continuou a crescer para a União e, de forma mais significativa ainda, para as empresas públicas. Em suma, as restrições legais não foram cumpridas.

Como explicar essa ação? O Senado não estaria, de fato, comprometido com o ajuste fiscal? Ou trata-se de um comportamento simplesmente incoerente e irracional dos senadores?

Parece-me mais apropriado caracterizar o comportamento do Senado como ambivalente mais do que irracional. Se, de um lado, o Senado não cumpre as regras que ele mesmo estabeleceu, de outro, há evidências de que ele está comprometido com o ajuste fiscal.

$\mathrm{Na}$ condição de representante de seu estado na arena política nacional e percorrendo uma carreira que passa na maioria das vezes por cargos executivos, o senador brasileiro sofre pressões dos governadores, que muitas vezes foram seus colegas no Senado, ao mesmo tempo em que está bastante envolvido com compromissos de governo. Assim, o endividamento, como uma das fontes importantes de geração de recursos para atender a demandas so-
TABELA 1

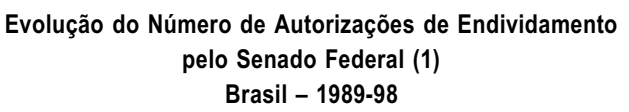

\begin{tabular}{rrrcrr}
\hline Anos & União & Estados & Municípios & Estatais & Total \\
\hline 1989 & 18 & 34 & 14 & 12 & 78 \\
1990 & 9 & 38 & 15 & 2 & 64 \\
1991 & 9 & 34 & 13 & 4 & 60 \\
1992 & 12 & 30 & 25 & 1 & 68 \\
1993 & 10 & 29 & 68 & 6 & 113 \\
1994 & 19 & 43 & 16 & 2 & 80 \\
1995 & 6 & 31 & 9 & 2 & 48 \\
1996 & 11 & 52 & 20 & 8 & 91 \\
1997 & 16 & 75 & 16 & 2 & 109 \\
1998 & 17 & 57 & 9 & 10 & 93 \\
\hline
\end{tabular}

Fonte: Senado Federal.

(1) Referem-se a autorizações para endividamento em bancos estrangeiros, em agências internacionais e no mercado interno de títulos públicos.

ciais inadiáveis, torna-se caminho praticamente irrecusável para um político, mesmo fazendo parte do Senado, órgão que tem como função constitucional garantir o equilíbrio financeiro dos entes federativos. ${ }^{13}$

Mesmo atendendo às demandas políticas, não se pode negar o comprometimento do Senado com o ajuste fiscal. Ele se revela de forma clara na delegação de poder para o Banco Central. Conhecendo a "fraqueza da vontade" a que estão sujeitos os senadores para resistir a pressões vindas dos governadores e de outros parlamentares, o Senado como que amarra as próprias mãos (Elster, 1979). E transfere para o Banco Central porção considerável de seu poder decisório em matéria de endividamento. ${ }^{14}$ Através das novas regras que dão ao Banco Central capacidade de emitir parecer conclusivo e de rejeitar, não encaminhando para a CAE, os pedidos que não preencham as condições legais, os senadores acabaram criando um mecanismo permanente para evitar pressões "irrecusáveis", ao mesmo tempo que acolhem as necessidades de controle do endividamento. ${ }^{15}$

Além disso, ao estabelecer limites claros para o endividamento, o Senado põe fim a um processo altamente politizado, resolvido caso a caso, e cujos custos tornavamse cada vez mais elevados, especialmente com o crescimento do consenso em torno da necessidade do equilíbrio fiscal. Em outras palavras, a despolitização dos pleitos de crédito e sua transformação em matéria técnica, de alçada da burocracia do Banco Central, mostra como a racionalidade política se acomoda com os ditames do ajuste fiscal no interior do Senado. 
O exame mais detalhado das autorizações para endividamento, posteriores ao ano de 1997, mostra que um número significativo delas ocorreu, na realidade, como parte do Programa de Apoio à Reestruturação e ao Ajuste Fiscal dos Estados e no bojo do processo de negociação das dívidas entre União e estados. Dentro desse programa, o Senado colaborou com o executivo federal, autorizando a renegociação das dívidas antigas dos estados, condicionada à privatização dos bancos estaduais e das empresas estatais. Como já se indicou, a privatização dos bancos estaduais tem sido vista como prioritária na agenda de ajuste fiscal do governo federal, na medida em que aqueles bancos foram usados durante muito tempo como alternativa de financiamento dos governos estaduais. Suprimir essa fonte significava, portanto, preencher uma condição para o ajuste das contas públicas.

Segundo números colhidos na Base de Dados da Legislação Brasileira, o Senado aprovou 18 autorizações, em 1996, dentro do programa mencionado; em 1997, foram 24, representando mais de $30 \%$ do total de autorizações concedidas para os governos estaduais. Em 1998, houve 16 autorizações, correspondendo a $28 \%$. Portanto, se elas forem descontadas do total, uma considerável redução aparecerá: ao invés das 75 (Tabela 1), o número de 1997 cai para 51, e o de 1998, para 41. Em outras palavras, as restrições legais acabaram sendo cumpridas, sob condições políticas específicas: a barganha entre governos federal e estados que levou à federalização das dívidas e à imposição de determinadas condições aos governos estaduais.

Outros indicadores servem ainda para reforço da argumentação: as restrições e limites impostos pela Resolução 78 sobre as operações ARO fizeram com que o número delas caísse drasticamente. Conforme dados do Banco Central, foram autorizadas no ano de 1996 e de 1997, respectivamente de 1.330 e 1.682 operações ARO para estados e municípios. Só no primeiro semestre de 1998, antes da Resolução 78, o número chegou a 1.227. A partir do segundo semestre de 1998, sob a vigência da nova regra, tais operações despencaram para 46 e em todo o ano de 1999 elas não passaram de 128.

Esses dados são significativos pois permitem analisar o comportamento do Senado em perspectiva ampliada. Mesmo sensível a pressões vindas dos governos estaduais (politicamente inevitáveis), ele tem se mostrado comprometido com o ajuste fiscal. Isso se mostra não só na partitha de nova "cultura da responsabilidade fiscal", que visivelmente vira consenso nos meios políticos e na opinião pública, mas sobretudo na colaboração com a agenda governamental em matéria fiscal, através de suas resoluções restritivas ao endividamento público. A aprovação conjunta - Senado e Câmara - da Lei de Responsabilidade Fiscal, em 2000, com rapidez e sem mudanças substantivas no projeto original do Executivo, também reforça a argumentação que se vem fazendo acerca do apoio do Senado à agenda de governo. E ainda valida a afirmação de que o Legislativo no Brasil, diferentemente do que se costumava pregar, não tem sido de fato um "obstáculo à governabilidade" (Palermo, 2000).

Como já se indicou, a despeito da ausência de disciplina partidária e da necessidade de negociar continuamente seus projetos, o governo atual, mais ainda do que os anteriores, tem tido sucesso na aprovação de sua agenda no Legislativo, e obtido apoio dos partidos no Congresso (Figueiredo e Limongi, 1999; Couto e Abrucio, 1999). Essa capacidade se manifesta ainda mais acentuadamente no Senado, onde os principais partidos que compõem a base de sustentação do governo (PSDB, PFL, PMDB) detêm quase $70 \%$ das cadeiras. ${ }^{16}$

Em apoio ao governo, a bandeira do equilíbrio das contas públicas e da responsabilidade fiscal entre os entes federativos tornou-se tema reiterado do discurso de parte significativa dos senadores. E isso não só entre os líderes da bancada governista. Vale transcrever aqui alguns trechos de debates ocorridos no Senado desde 1995, que culminaram na aprovação da Resolução 78 , em julho de 1998. Eles revelam bem a tensão entre a lógica política e a necessidade de impor restrições aos governos subnacionais: "Nem eu nem nenhum dos senadores têm interesse em inviabilizar a administração pública de nenhum estado. Agora, precisamos (...) pensar um pouco no país sob o seguinte aspecto: quando vamos parar com essa história de o prefeito passar a conta para o governador, o governador passar para o presidente e este para o povo? Quando vamos criar mecanismos de austeridade administrativa nos estados?" (Senador Wilson Kleinübing, Ata da $28^{a}$ Reunião da CAE/Senado Federal, 13/09/1995).

"A bandeira do ajuste fiscal é bandeira sempre atual e todo político deve lutar por ela. Eu aqui no Senado, na CAE, tenho sido inflexível na concessão de empréstimo para estados e municípios" (Senador Carlos Bezerra, do PMDB de Mato Grosso).

"Gostaria de deixar consignado nas notas taquigráficas desta reunião da CAE (...) que estamos votando um dos projetos mais importantes que já passaram por esta casa. Sem dúvida alguma, com o projeto de autoria do senador 
Espiridião Amin, bem como de vários outros senadores cujos projetos foram apensados, sob a brilhante relatoria do senador Wilson Kleinübing, que discutiu e levou a cabo um dos projetos mais sérios e competentes, hoje, no Senado Federal, de moralização de financiamentos para estados e municípios" (Senador Gilberto Miranda). ${ }^{17}$

“(...) Chegou a hora da verdade. Não vamos mais empurrar problemas com a barriga e nem mandar a conta para a viúva. Ontem nesta sala, quando um senador, meu colega, fazia um discurso e dizia que a União tem que resolver os problemas dos estados, eu perguntei: 'Quem vai resolver os problemas da União?'. Sou representante do Estado do Amazonas, mas sou senador da República. Não posso adotar a posição irresponsável de dizer: mande para a União e o resto que se dane" (Senador Jefferson Peres, Ata da 14a Reunião da CAE/Senado Federal, 16 /06/1998).

Em suma, mesmo que a lógica política (aí incluída a pressão clientelista) muitas vezes se sobreponha à austeridade, é importante levar em conta que a orientação fiscalista, não só entre burocratas, mas igualmente entre parlamentares, vem se afirmando no País e já produziu para o bem ou para o mal - efeitos políticos consideráveis. As resoluções do Senado e agora a Lei de Responsabilidade Fiscal são prova disso.

\section{CONSIDERAÇÕES FINAIS}

O institucionalismo tem se tornado hegemônico nas ciências sociais contemporâneas, dando ênfase ao papel que as regras formais e informais desempenham na estratégia dos atores políticos e nos resultados da ação governamental. Sem negar seus achados, este texto procurou mostrar que as regras legais, especialmente em matéria fiscal, não bastam para garantir sua efetividade e, daí, cumprir seu papel nas políticas públicas. Elas pressupõem certas condições políticas. No caso em estudo, as normas estabelecidas pelo Senado só começaram a ser implementadas em um contexto político bem determinado: quando se consolida o consenso em torno da responsabilidade fiscal e sobretudo quando o governo federal ganha mais força nas relações federativas.

Foram igualmente deixadas de lado concepções que insistem em ver os políticos como atores incapazes de satisfazer qualquer racionalidade, que não a de seus interesses eleitorais (vistos com desprezo). A análise derruba ainda o vezo de opor a ação política - considerada sempre irracional, ineficiente e mesmo perversa - à ação técnica, esta sim vista como racional e eficiente.
Ao contrário, o Senado é tomado como um espaço político no qual há possibilidades de ação coletiva fundada na combinação de racionalidade política e racionalidade técnica. Em outras palavras, ele não age sempre no sentido oposto ao da racionalidade que prega o equilíbrio das contas públicas e a responsabilidade fiscal. Em vários momentos, o Senado tem atuado nessa direção, podendo exprimir o processamento institucional entre os constrangimentos fiscais necessários à saúde orçamentária e administrativa e as demandas políticas. Estas são não só inevitáveis, mas legítimas em uma ordem democrática. A propósito, é pertinente relembrar a sempre atual advertência de Max Weber de que fora da política não há salvação para a vocação inerentemente autoritária do Estado (e, acrescente-se, dos dirigentes que tendem a impor seus pontos de vista como verdade inquestionável).

\section{NOTAS}

E-mail da autora: mrloureiro@yahoo.com

Os dados que serviram de base para este texto fazem parte de pesquisa mais ampla sobre o controle do endividamento público nos Estados Unidos e no Brasil, financiada pelo Núcleo de Estudos e Publicações (NPP) da Fundação Getúlio Vargas de São Paulo, ao qual, nesta oportunidade reitero meus agradecimentos.

1. Em termos de inflação, de elevação da taxa de juros e ainda o peso que o pagamento do serviço da dívida possa representar nos gastos públicos.

2. Cabe esclarecer que o âmbito deste trabalho, que examina a lógica de ação do Senado, não se atém às diferenças entre o Senado e a Câmara dos Deputados em termos de suas atribuições e poder respectivo dentro do sistema político, como é comum nos estudos comparativos sobre as câmaras altas (Oleszek, 1996; Lijphart, 1989).

3. No conceito de endividamento público estão incluídas as dívidas mobiliárias, isto é, aquelas originárias da venda de títulos públicos no mercado e a dívida contratual, constituída de créditos obtidos no país ou no exterior para financiamento de projetos específicos (Ver, a respeito, o artigo 52 da Constituição Federal de 1998 e as atas das reuniões da CAE, indicadas nas referências bibliográficas).

4. Cabe lembrar que durante o regime militar o controle do endividamento público estava circunscrito ao raio de influência do Executivo, mais especialmente ao Ministério da Fazenda. A Lei Complemen$\operatorname{tar}^{\circ} 12$ de 1971, promulgada no período em que Delfim Netto esteve à frente daquele ministério, transferiu para o Banco Central e o Conselho Monetário Nacional o poder de autorizar a emissão de títulos públicos.

5. Os gastos com pessoal (ativos e inativos) têm sido outra fonte importante das dificuldades financeiras dos governos subnacionais. Mesmo com a redução do número de servidores, a folha de pagamento cresce constantemente em decorrência de benefícios legais automáticos (Beltrão, Abrucio e Loureiro, 1998).

6. Relatórios do Banco Central e Informações Fipe, $n^{\circ} 248$, maio de 2001.

7. Entende-se por superávit primário o resultado positivo entre receita e despesa, excluindo-se o pagamento de juros. Os superávits primários são vistos como necessários para a redução do peso da dívida pública frente ao PIB. Como resultado de vários anos de contenção dos 
gastos e de elevação da carga tributária bruta (que passou de cerca de $22 \%$ do PIB em 1994 para mais de 30\% do PIB hoje), o setor público vem apresentando superávits primários nos últimos anos: no primeiro trimestre de 2001, por exemplo, a União e os governos subnacionais geraram superávits primários respectivamente de 9,5 bilhões de reais ( $3,8 \%$ do PIB) e 5,4 bilhões ( $1,8 \%$ do PIB) (Informações Fipe, $n^{\circ} 248$, maio de 2001)

8. Como apontou recentemente um jornalista econômico, "quanto maior for o superávit primário, mais o governo poderá pagar de juros e evitar que cresça a dívida líquida total, que é o número-chave para traduzir o risco de uma moratória futura" (Pinto, 2001:A2).

9. Pode-se citar, como exemplo, a ajuda do governo federal, em 1994, aos bancos estaduais para obter apoio no Congresso e facilitar a articulação da candidatura de Fernando Henrique Cardoso à presidência da República. Nessa época, a União comprou títulos dos bancos estaduais, considerados "podres" pelo mercado no valor de 5 bilhões de dólares, ou seja, mais do que o dobro do que foi injetado em todas as instituições financeiras nos seis anos anteriores (conforme dados publicados em O Estado de S. Paulo apud Abrucio e Costa, 1998:47).

10. Segundo o texto: "O Banco Central e o Senado estavam aceitando tudo o que lhes era apresentado, não questionando o valor ou a existência dos precatórios listados, nem levantando a possibilidade de que tais débitos já poderiam ter sido pagos.(...) Quanto mais se percebia que o Banco Central e o Senado não estavam sendo suficientemente vigilantes, mais se exagerava na correção monetária dos precatórios devidos" (Senado Federal, 1997:44, grifo meu).

11. Isso é crucial para impor responsabilidade fiscal em uma federação. Nos Estados Unidos, por exemplo, o fato de credores e estados saberem que a União não socorrerá os governos devedores desestimula práticas predatórias e o chamado moral hazard (Loureiro, 1999).

12. É importante ressaltar que as resoluções de $\mathrm{n}^{\text {os }} 2.443$ e 2.444 de 1997 do Conselho Monetário Nacional (CMN) também exerceram papel fundamental neste processo, atuando do lado da limitação da oferta de crédito ao setor público pelo sistema financeiro nacional.

13. Eis o que diz a respeito um dos senadores entrevistados: "Quando a solicitação do Estado ou município está no limite do previsto nas resoluções, na 65 e agora na 78, ainda assim há pressão dos governadores, dos secretários e parlamentares. Há exemplos semanais (dessa pressão). (...) O senador Suruagy havia estado no Senado por 8 anos, quando foi eleito governador. (Como tinha muita) interação com os senadores, foi conversando com eles para que dessem atenção às suas solicitações. E depois não se imaginava que ele iria fazer o que fez".

14. O artigo VII da Resolução 78/98 assim estabelece: "O Banco Central do Brasil não encaminhará ao Senado Federal pedido de autorização para a contratação de qualquer operação de crédito de tomador que apresente resultado primário negativo no período de apuração da Receita Líquida Real ou que esteja inadimplente junto a instituições integrantes do Sistema Financeiro Nacional” (grifo meu).

15. São expressivas estas palavras: "Se as matérias sobre endividamento não são remetidas para o Senado, se são triadas dentro do Bacen, haverá menos pressões políticas junto aos senadores. É uma atitude de autodefesa, porque se chega ao Senado um pedido de autorização de endividamento, é muito difícil resistir politicamente às pressões" (Funcionário da $\mathrm{CAE}$ )

16. $\mathrm{Na} 50^{\mathrm{a}}$ legislatura, correspondente ao primeiro mandato do governo Fernando Henrique Cardoso (1995-1999), as bancadas do PSDB, PFL e PMDB no Senado detinham respectivamente 14,8\%, 25,9\% e $28,3 \%$ de senadores.

17. Ata da $14^{\mathrm{a}}$ Reunião da $\mathrm{CAE} /$ Senado Federal, realizada no dia 16 de junho de 1998, na qual se aprovou a Resolução 78/98. É interessante lembrar aqui que o senador Gilberto Miranda foi justamente um dos que haviam exercido pressão junto a CAE para aprovar pedidos de autorização para emissão de títulos precatórios para a Prefeitura de São Paulo, durante a administração de Paulo Maluf, de quem o senador Gilberto Miranda era aliado político.

\section{REFERÊNCIAS BIBLIOGRÁFICAS}

ABRANCHES, S. "Presidencialismo de coalizão: o dilema institucional brasileiro". Dados, v.31, 1988, p.5-38.

ABRUCIO, F. e COSTA, V. "Reforma do Estado e o Contexto Federativo Brasileiro". Pesquisa, n.12. Fundação Konrad Adenauer, 1998.

AFFONSO, R. "A questão tributária e o financiamento dos diferentes níveis de governo". In: AFFONSO, R. e SILVA, P.L. (orgs.). $A$ Federação em Perspectiva. Ensaios Selecionados. São Paulo, Fundap/Unesp, 1995.

AMORIM, O. "Formação de Gabinetes Presidenciais no Brasil: Coalização versus Cooptação". Nova Economia. Belo Horizonte, v.4, n.1, nov. 1994.

"Gabinetes presidenciais, ciclos eleitorais e disciplina legislativa no Brasil". Dados, v.43, n.3, 2000, p.479-519.

BELTRÃO, R.; ABRUCIO, F. e LOUREIRO, M.R. "Reforma da burocracia pública e federalismo no Brasil: a experiência do Programa de Demissão Voluntária nos Governos Estaduais". Revista de Administração Pública, v.32, n.6, nov.-dez. 1998.

BENAVIE, A. Déficit Hysteria. A Common Sense Look at America's Rush to Balance the Budget. Praeger. West Port. Connecticut. London, 1998.

BRIFFAULT, R. Balancing Acts. The Reality Behind State Balanced Budget Requirements. Nova York, The Twentieth Century Fund Press, 1996.

CLIGERMAYER, J. e DAN WOOD, B. "Disentangling Patterns of State Debt Financing". American Political Science Review, n.89, 108, 1995.

COUTO, A. e ABRUCIO, F. "Arenas políticas e agenda econômica: os caminhos institucionais do Real”. Reunião Anual da Anpocs. Caxambu, out. 1999.

DIÁRIO DO SENADO FEDERAL. Atas da Comissão de Assuntos Econômicos. Brasília, 1995 a 1998. 1997.

Relatório Final. CPI dos Títulos Públicos. Brasília, ago.

ELSTER, J. Ulysses and the Sirens. Cambridge University Press, 1979.

EVANS, G. Red Ink. The Budget, Déficit, and Debt of Us. San Diego, London, Government. Academic Press, 1997.

FERREIRA, I. A economia política do endividamento público em uma federação. Um estudo comparativo entre o Brasil e os Estados Unidos. São Paulo, Fundação Getúlio Vargas, 1998.

FIGUEIREDO, A. e LIMONGI, F. "Partidos políticos na Câmara dos Deputados: 1989-1994". Dados, v.38, n.34, 1995, p.497-524.

Executivo e Legislativo na nova ordem constitucional. Rio de Janeiro e São Paulo, Fundação Getúlio Vargas/Fapesp, 1999.

LIJPHART, A. As democracias contemporâneas. Lisboa, Gradiva, 1989.

LOUREIRO, M.R. "O controle do endividamento público nos Estados Unidos e no Brasil". Relatório de Pesquisa. São Paulo, NPP/FGV, 1999.

Os economistas no Governo: gestão econômica e democracia. Rio de Janeiro, Editora da FGV, 1997.

MAINWARING, S. "Democracia presidencialista multipartidária: o caso do Brasil". Lua Nova. São Paulo, Cedec, n.28/29, 1993.

"Multipartism, Robust Federalism and Presidentialism". In: MAINWARING, S. e SHUGART, M. (eds.). Presidentialism and Democracy in Latin America. Cambridge University Press, 1997.

NICOLAU, J. "Disciplina Partidária e Base Parlamentar na Câmara dos Deputados no Primeiro Governo Fernando Henrique Cardoso (1995-1998)". Dados, v.43, n.4, 2000, p.909-735. 
OLESZEK, W. Congressional Procedures and the Policy Process. A Division of Congressional Quartely Inc. Washington, D.C., 1996.

PALERMO, V. "Como se governa o Brasil? O debate sobre instituições políticas e gestão de Governo". Dados. Rio de Janeiro, v.43, n.3, 2000, p.521-57.

PESSANHA, C. Relações entre os Poderes Executivo e Legislativo no Brasil: 1946-1994. Tese de doutorado. São Paulo, USP, 1997.

PETERSON, P. The Price of Federalism. Washington, D.C. The Brokings Institute, 1995.

PINTO, C. "A dívida fiscal volta a preocupar". Valor Econômico, 21/ 06/2001, p.A2.

ROSS, J. What Would a Balanced Budget Means for California? Nova York, The Century Foundation, 1999.

SALLUM Jr., B. e KUGELMAS, E. "O Leviatã acorrentado: a crise brasileira dos anos 80". In: Sola, L. (org.). Estado, mercado e demo- cracia: politica e economia comparadas. Rio de Janeiro, Paz e Terra, 1993.

SCHICK, A. "Governments versus Budget Déficits". In: WEAVER, K. e ROCKMAN, B. Op. cit., 1993.

SENADO FEDERAL. Relatório final da CPI dos títulos públicos. Brasília, 1997.

SOLA, L.; GARMAN, C. e MARQUES, M. "Central Banking, Democratic Governance and politcal authority." XVII International Congress. IPSA. Seul, Korea, 1997.

TONETO Jr., R. e GREMAUD, A. "Por que não um mercado de títulos municipais?" Informações Fipe, n.239, ago. 2000.

WEAVER, K e ROCKMAN, B. Do Institutions Matter? Governmnet Capabilities in the United States and Abroad. The Brookings Institution. Washington, D.C., 1993.

WERNECK, R. “A União e a Dívida dos Estados”. O Estado de S.Paulo, $13 / 06 / 1998$ 